\title{
PENGARUH CURRENT RATIO (CR), DEBT TO EQUITY RATIO (DER) DAN RETURN ON EQUITY (ROE) TERHADAP DIVIDEND PAYOUT RATIO (DPR) PADA PERUSAHAAN SEKTOR INDUSTRI BARANG KONSUMSI DI BURSA EFEK INDONESIA (BEI) TAHUN $2013-2017$
}

\author{
Dianty Putri Purba ${ }^{1}$, Sheren $^{2}$, Valent $^{3}$, Angeline $^{4}$ \\ ${ }^{1,2,3,4}$ Program Studi S-1 Akuntansi Keuangan Universitas Prima Indonesia (UNPRI), Jl.Belanga No.1, Medan, \\ 20112, Indonesia
}

Email: sherenchow97@gmail.com

\begin{abstract}
The objective of this study is to analyze the effect of current ratio $(C R)$, debt to equity ratio (DER), and return on equity (ROE) to dividend payout ratio (DPR) on consumer goods industry listed in Indonesia Stock Exchange along period of 2013-2017. This study uses quantify method with explanatory approach. The sample of this study is 41 firms and conducts multiple regressions for hypothesis testing. This study shows that current ratio, debt to equity ratio, and return on equity simultaneously effect on dividend payout ratio for consumer goods industry listed in Indonesia Stock Exchange along period of 2013-2017 with result $F=15,303$. Partially, current ratio and debt to equity ratio are insignificant to dividend payout ratio while return on equity has significant and positive with result $t=5,398$. The determinant coefficient of 0,352 shows that CR, DER, and ROE can explain DPR for 35,2\% while the rests or about 64,8\% can be explained by other factors excluded for this study. Keywords : current ratio, debt to equity ratio, return on equity. dividend payout ratio.
\end{abstract}

\section{PENDAHULUAN}

Bursa Efek Indonesia sebagai salah satu pasar modal yang dapat dijadikan alternatif pendanaan bagi semua sektor perusahaan di Indonesia. Dengan demikian Bursa Efek Indonesia telah menjadi bagian penting dari berkembangnya perekonomian Indonesia. Sektor industri barang konsumsi telah mengalami perkembangan yang pesat dan mempengaruhi perekonomian Indonesia, dan juga menyediakan lapangan perkerjaan yang cukup besar untuk masyarakat. Seiring dengan jumlah penduduk yang besar, tingkat konsumsi masyarakat juga ikut meningkat yang menjadikan Indonesia dikenal dunia sebagai target pasar potensial. (https://www.seputarforex.com/analisa/lihat.php?id=208100\&title=mariintip-saham-sektorkonsumsi-yang-menarik).

Harapan dan tujuan investor dari investasi yang dilakukan di pasar modal pada umumnya adalah untuk mencari pendapatan atau return yang berupa pendapatan (dividend) ataupun pendapatan selisih harga jual saham terhadap harga beli (capital gain). Perusahaan yang akan membagikan dividen tergantung pada keputusan perusahaan apakah perusahaan harus membayar semua net income sebagai dividen atau menahan sebagian atau semua laba bersih untuk reinvestasi. Kebijakan dividen sering dianggap sebagai sinyal untuk para investor dalam menilai baik buruknya kinerja suatu perusahaan serta menjadi sumber pendapatan bagi investor. Perusahaan yang memilih untuk membagikan labanya sebagai dividen, akan mengurangi total sumber dana internal atau internfinancing. Sedangkan investor tidak ingin mengambil risiko lebih banyak sehingga lebih menyukai pembagian dividen yang tinggi daripada capital gain. Namun pembagian dividen yang tinggi kurang disukai oleh manajemen karena akan mengurangi utilitas manajemen yang disebabkan oleh semakin kecilnya dana yang berada dalam ruang lingkup kendali manajemen. 
Pentingnya dalam menjaga keseimbangan antara kepentingan perusahaan dengan kepentingan para pemegang saham, sehingga perlu dianalisis faktor-faktor yang mempengaruhi pembayaran dividen. Hal ini dikarenakan pendapatan yang diharapkan oleh pemegang saham adalah pendapatan yang dihasilkan dari pembagian dividen, dimana badan usaha menyerahkan sebagian labanya, untuk kepentingan kesejahteraan pemegang saham. Beberapa faktor yang dapat mempengaruhi pembayaran dividen (DPR) di antaranya yaitu CR, DER dan ROE.

\section{TINJAUAN PUSTAKA}

Current Ratio. Menurut Samryn (2013:411), current ratio merupakan rasio yang menunjukkan kemampuan suatu perusahaan membayar hutang jangka pendeknya dengan menggunakan aktiva lancar. Menurut Horne dan Wachowicz (2014:167-168), semakin tinggi rasio lancar, maka akan semakin besar kemampuan perusahaan untuk membayar berbagai tagihannya, akan tetapi rasio ini harus dianggap sebagai ukuran besar karena tidak memperhitungkan likuiditas dari setiap komponen aset lancer. Perusahaan yang memiliki aset lancar sebagian besar terdiri atas kas dan piutang yang belum jatuh tempo, umumnya akan dianggap sebagai lebih likuid daripada perusahaan dengan aset lancar sebagian besar terdiri atas persediaan. Menurut Sudana (2011:21) rumus untuk menghitung current ratio adalah :

$$
\text { Current Ratio }=\frac{\text { Current Asset }}{\text { Current liabilities }}
$$

Debt to Equity Ratio. Menurut Jusuf (2008:55), DER yaitu perbandingan antara total utang dengan total modal sendiri. Rasio ini menunjukkan sejauh mana modal sendiri menjamin seluruh utang. Rasio ini juga dapat dianggap sebagai perbandingan antara dana pihak luar dengan dana pemilik perusahaan yang dimasukkan ke perusahaan. Menurut Keown, et.al (2008:85), semakin tinggi tingkat pengembalian ekuitas pemegang saham, membuktikan bahwa perusahaan menghasilkan pengembalian atas investasi lebih besar daripada biaya utang. Jadi, dengan rasio hutang rendah perusahaan bisa meningkatkan dengan cepat pengembaliannya kepada pemilik dengan menggunakan lebih banyak hutang akan tetapi, semakin banyak hutang yang digunakan oleh perusahaan, semakin besar risiko keuangan perusahaan, yang juga akan mengakibatkan semakin besarnya risiko bagi pemegang saham. Menurut Harahap (2015:303), rumus untuk menghitung debt to equity ratio adalah:

$$
\text { Debt to equity ratio }=\frac{\text { Total utang }}{\text { Modal }}
$$

Return on Equity. Menurut Syahyunan (2013 : 94), Return on Equity mengukur kemampuan perusahaan memperoleh laba yang tersedia bagi pemegang saham perusahaan.Sedangkan menurut Wahyudiono (2014 : 82), Return on Equity sering juga disebut rentabilitas modal sendiri. Rasio ini digunakan untuk mengukur seberapa banyak keuntungan yang menjadi hak pemilik modal sendiri. Menurut Hery (2015 : 230), semakin tinggi ROE berarti semakin tinggi pula jumlah net income yang dihasilkan dari setiap rupiah dana yang tertanam dalam ekuitas begitu juga dengan sebaliknya.

$$
\text { Return on equity }=\frac{\text { Earnings after interest and tax }}{\text { Equity }}
$$

Dividend Payout Ratio. Menurut Sudana (2011:24) DPR mengukur berapa besar bagian net income after tax yang dibayarkan sebagai dividen kepada pemegang saham. 
Menurut Wahyudiono (2014 : 122), dividen adalah bagian keuntungan perusahaan yang dibagikan kepada pemegang saham. Para pemegang saham akan mendapatkan pembagian dividen sesuai dengan jumlah saham yang telah dibelinya, besarnya dividen ditentukan oleh RUPS (Rapat Umum Pemegang Saham). Perusahaan yang mengeluarkan emiten pada umumnya memberikan laporan keuntungan secara periodik per 6 bulan dan akhir tahun. Dividen biasanya dibayarkan per tahun. Jumlah dividen yang dibagikan tidak selalu sama karena bergantung dari keuntungan yang dihasilkan perusahaan. Menurut Murhadi (2015:65) rumus Dividend Payout Ratio adalah :

$$
\text { Dividend Payout Ratio }=\frac{\text { Dividend }}{\text { Net Income }}
$$

Adapun kerangka konseptual dalam penelitian ini adalah:

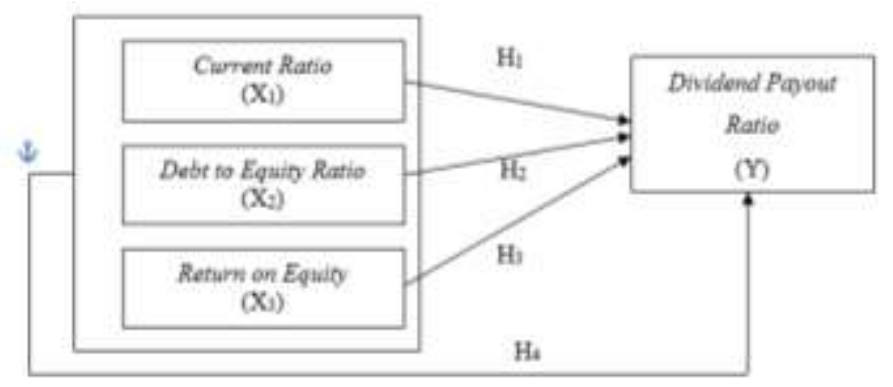

\section{Gambar 1. Kerangka Konseptual}

Hipotesis Penelitian. Adapun hipotesis dalam penelitian ini adalah sebagai berikut:

1. CR berpengaruh terhadap DPR pada perusahaan sektor industri barang konsumsi di Bursa Efek Indonesia (BEI) tahun 2013-2017.

2. DER berpengaruh terhadap DPR pada perusahaan sektor industri barang konsumsi di Bursa Efek Indonesia (BEI) tahun 2013-2017.

3. ROE berpengaruh terhadap DPR pada perusahaan sektor industri barang konsumsi di Bursa Efek Indonesia (BEI) tahun 2013-2017.

4. CR, DER, dan ROE berpengaruh terhadap DPR pada perusahaan sektor industri barang konsumsi di Bursa Efek Indonesia (BEI) tahun 2013-2017.

\section{METODE PENELITIAN}

Jenis dan Sumber Data. Jenis data yang dikumpulkan adalah data kuantitatif sehingga data dapat diukur berupa angka-angka dalam laporan keuangan. Sumber data yang digunakan dalam penelitian ini merupakan data sekunder yang berasal dari laporan keuangan perusahaan sektor industri barang konsumsi tahun 2013 sampai dengan tahun 2017, yang diperoleh dari situs web http://www.idx.co.id. Data yang dibutuhkan adalah informasi keuangan yang berhubungan dengan variabel penelitian.

Sampel dan Teknik Pengambilan Sampel. Teknik pengambilan sampel dalam penelitian ini adalah berdasarkan purposive sampling. Menurut Sugiyono (2010:85), sampling purposive adalah teknik penentuan sampel dengan pertimbangan tertentu. Adapun kriteria-kriteria dalam pemilihan sampel adalah sebagai berikut: 
Tabel 1. Pemilihan Sampel

\begin{tabular}{llc}
\hline No & \multicolumn{1}{c}{ Keterangan } & Jumlah \\
\hline 1. & Perusahaan consumer goods yang terdaftar di BEI & 42 \\
2. & $\begin{array}{l}\text { Perusahaan sektor industri barang konsumsi yang tidak mempublikasikan } \\
\text { laporan keuangan secara lengkap berturut-turut dari tahun 2013-2017 }\end{array}$ & $(11)$ \\
3. $\begin{array}{l}\text { Perusahaan sektor industri barang konsumsi yang mengalami kerugian } \\
\text { berturut-turut tahun 2013-2017 }\end{array}$ & $(7)$ \\
4. $\begin{array}{l}\text { Perusahaansektor industri barang konsumsi yang tidak membagikan dividen } \\
\text { berturut-turut tahun 2013-2017 } \\
\text { Jumlah sampel penelitian }\end{array}$ & $\mathbf{1 6}$ \\
\hline
\end{tabular}

Metode pengumpulan data dalam penelitian ini dilakukan dengan studi dokumentasi yang merupakan teknik pengumpulan dengan cara mencatat, mengumpulkan, dan mempelajari data-data perusahaan terkait masalah yang sedang diteliti.

Metode Analisis. Metode analisis yang digunakan dalam penelitian ini adalah metode regresi linier berganda.

\section{HASIL ANALISIS DAN PEMBAHASAN}

\subsection{Hasil Penelitian}

Sampel yang memenuhi kriteria pada penelitian ini adalah 16 perusahaan industri barang konsumsi periode 2013-2017 sehingga data penelitiannya yang diperoleh berjumlah 80. Hasil pengolahan data sampel dapat dilihat dari statistik deskriptif di bawah ini:

Tabel 2. Statistik Deskriptif

\begin{tabular}{|c|c|c|c|c|c|}
\hline & $\mathbf{N}$ & Minimum & Maximum & Mean & Std. Deviation \\
\hline CR & 80 & ,196 & ,900 & ,61161 & ,164728 \\
\hline DER & 80 & , 171 & 3,029 & ,77655 & ,623666 \\
\hline $\mathrm{ROE}$ & 80 & 017 & 1,435 & 31811 & ,370349 \\
\hline DPR & 80 & 057 & 1,540 & ,52063 & ,312201 \\
\hline Valid N (listwise) & 80 & & & & \\
\hline
\end{tabular}

Sumber : Hasil Pengolahan Data ,2018

Variabel Current Ratio memiliki jumlah sampel (N) sebanyak 80, dengan nilai minimum (terkecil) adalah sebesar 0,196 yang diperoleh pada PT. Nippon Indosari Corporindo, Tbk tahun 2014. Nilai maksimum (terbesar) Current Ratioadalah sebesar 0,900yang diperoleh pada PT. Delta Djakarta, Tbk tahun 2017. Nilai rata-rata Current Ratio industri barang konsumsi periode 2013-2017adalah 0,61161. VariabelDebt to Equity Ratiomemiliki jumlah sampel $(\mathrm{N})$ sebanyak 80, dengan nilai minimum (terkecil) adalah sebesar 0,171yang diperoleh padaPT. Delta Djakarta, Tbk tahun 2017. Nilai maksimum (terbesar) Debt to Equity Ratioadalah sebesar 3,029 yang diperoleh pada PT. Multi Bintang Indonesia, Tbk tahun 2014. Nilai rata-rata Debt to Equity RatioIndustri barang konsumsi periode 2013-2017 adalah 0,77655. Variabel Return on Equity memiliki jumlah sampel (N) sebanyak 80, dengan nilai minimum (terkecil) adalah sebesar 0,017 yang diperoleh pada PT. Indofood CBP Sukses Makmur, Tbk tahun 2013. Nilai maksimum (terbesar) Return on Equity adalah sebesar 1,435 yang diperoleh pada PT. Multi Bintang Indonesia, Tbk tahun 2014. Nilai rata-rata Return on Equity industri barang konsumsi periode 2013-2017 adalah 0,31811. Variabel Dividend Payout Ratio memiliki jumlah sampel (N) sebanyak 80, dengan nilai minimum (terkecil) adalah sebesar 0,057yang diperoleh pada PT. Wismilak Inti 
Makmur, Tbk tahun 2013. Nilai maksimum (terbesar) Dividend Payout Ratio adalah sebesar 1,540 yang diperoleh pada PT. Merck, Tbk tahun 2015. Nilai rata-rata Dividend Payout Ratio Industri barang konsumsi periode 2013-2017 adalah 0,52063.

Hasil Uji Asumsi Klasik. Data pada penelitian ini telah memenuhi syarat uji asumsi klasik yaitu berdistribusi normal, tidak terjadi multikolinearitas, tidak terjadi autokorelasi dan tidak terjadi heteroskedastisitas. Berikut hasil uji asumsi klasik yang terdiri dari uji normalitas, uji multikolinearitas, uji autokorelasi dan uji heteroskedastisitas.

Uji Normalitas. Menurut Ghozali (2013:160), uji normalitas bertujuan untuk menguji apakah dalam model regresi, variabel pengganggu atau residual memiliki distribusi normal. Model regeresi yang baik adalah yang memiliki data residual yang terdistribusi secara normal yang memiliki tingkat signifikan lebih bersar dari 0,05. Uji yang dilakukan dalam normalitas ini adalah dengan melihat grafik Histogram, P-P Plots dan Kolmogorov-Smirnov.Kalau uji normalitas ini dilanggar maka uji statistik menjadi tidak valid untuk jumlah sampel yang kecil.

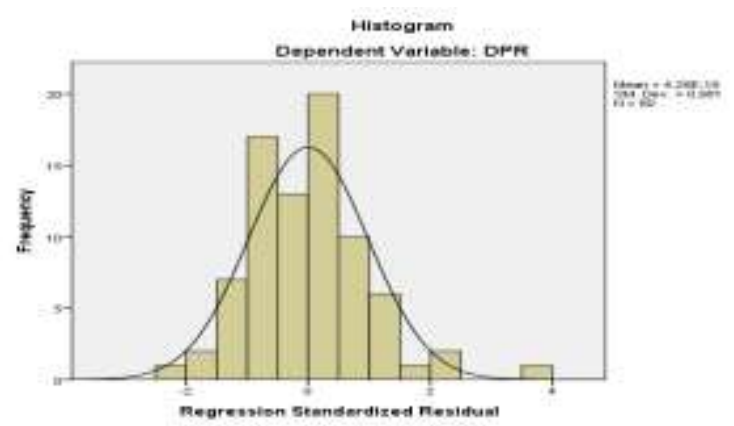

\section{Gambar 2. Grafik Uji Normalitas Histogram}

Sumber : Hasil Pengolahan Data,2018

Grafik histogram pada Gambar 2 di atas menunjukkan garis kurva cenderung simetri (U) maka dapat dikatakan data telah berdistribusi normal.

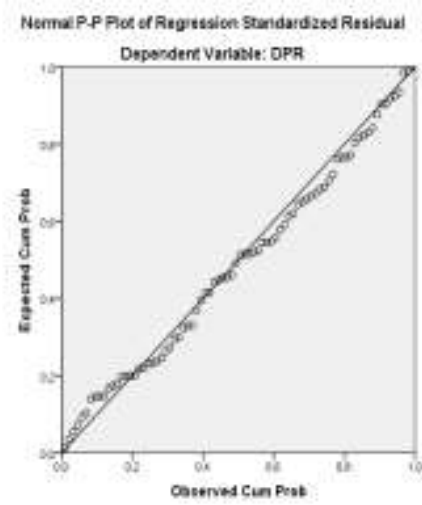

\section{Gambar 3. Grafik Uji Normalitas P-P Plot}

Sumber : Hasil Pengolahan Data,2018

Grafik normalitas P-P Plot pada Gambar 3, terlihat titik-titik menyebar mendekati garis diagonal sehingga dapat dikatakan bahwa model regresi memenuhi asumsi normalitas. Selain analisis grafik, perlu dilakukan analisis statistik untuk memastikan apakah data benar-benar berdistribusi normal. Pengujian normalitas secara statistik menggunakan uji kolmogorov smirnovtest yang hasil pengujiannya dapat dilihat pada tabel berikut ini : 
Tabel 3. Uji NormalitasKolmogorov Smirnov

\begin{tabular}{llr}
\hline & & \multicolumn{2}{c}{ Unstandardized Residual } \\
\hline N & & 80 \\
Normal Parameters & Mean & $0 \mathrm{E}-7$ \\
& Std. Deviation &, 24650338 \\
& Absolute &, 060 \\
Most Extreme Differences & Positive &, 058 \\
& Negative &,- 060 \\
Kolmogorov-Smirnov Z & &, 534 \\
Asymp. Sig. (2-tailed) & &, 938 \\
\hline
\end{tabular}

a. Test distribution is Normal.

b. Calculated from data.

Sumber : Hasil Pengolahan Data, 2018

Hasil uji normalitas Kolmogorov Smirnov menunjukkan nilai signifikan sebesar 0,938 dimana lebih besar dari 0,05. Jadi dengan demikian hasil uji normalitas KolmogorovSmirnov dapat diambil kesimpulan data penelitian berdistribusi normal.

Uji Multikolinearitas. Untuk mengetahui ada tidaknya multikolonieritas antar variabel-variabel independent dapat dilakukan dengan melihat nilai VIF (Variance Inflation Factor) dan Tolerance. Nilai tolerance yang rendah sama dengan nilai VIF yang tinggi (karena VIF $=1 /$ Tolerance) .

Tabel 4. Uji Multikoloniearitas

\begin{tabular}{ccccc}
\hline \multirow{2}{*}{ Model } & & \multicolumn{2}{c}{ Collinearity Statistics } \\
\cline { 3 - 5 } & & \multicolumn{3}{c}{ Tolerance } \\
\hline \multirow{2}{*}{1} & CR &, 596 & 1,678 \\
& DER &, 303 & 3,305 \\
& ROE &, 430 & 2,327 \\
\hline
\end{tabular}

a. Dependent Variable: DPR

Sumber : Hasil Pengolahan Data, 2018

Hasil uji multikolinearitas menunjukkan nilai toleranceCurrent Ratio sebesar 0,596 > 0,1 dan VIF 1,678 < 10, nilai tolerance Debt to Equity Ratio sebesar 0,303 > 0,1 dan VIF $3,305<10$, nilai toleranceReturn on Equity sebesar 0,430 > 0,1 dan VIF 2,327 < 10. Dengan demikian hasil uji Multikolinearitas dapat disimpulkan tidak terjadi regresi antar variabel independen Current Ratio, Debt to Equity Ratio dan Return on Equity karena semua variabel independen memiliki nilai tolerance diatas 0,1 dan nilai VIF dibawah 10.

Uji Autokorelasi. Uji ini bertujuan untuk menguji apakah dalam model regresi linier ada korelasi antara kesalahan pengganggu pada periode $t$ dengan kesalahan pengganggu pada periode t-1 (sebelumnya). Untuk mengetahui ada atau tidak nya autokolerasi dalam suatu model penelitian, maka dapat diukur berdasarkan uji Durbin Watson. Hasil penelitian uji autokorelasi dapat dilihat pada tabel berikut:

Tabel 5. Uji Autokorelasi

\begin{tabular}{lrrrrr}
\hline Model & R & R Square & $\begin{array}{c}\text { Adjusted R } \\
\text { Square }\end{array}$ & $\begin{array}{c}\text { Std. Error of } \\
\text { the Estimate }\end{array}$ & Durbin-Watson \\
\hline 1 &, $614^{\mathrm{a}}$ &, 377 &, 352 &, 251321 & 1,906 \\
\hline $\begin{array}{l}\text { a. Predictors: (Constant), ROE, CR, DER } \\
\text { b. Dependent Variable: DPR }\end{array}$ & & & & \\
Sumber : Hasil Pengolahan Data, 2018 & & & & \\
\hline
\end{tabular}


Hasil uji Durbin-Watson menunjukkan nilai sebesar 1,906; sedangkan dalam tabel DW untuk "k" $=3$ (variabel bebas, tidak termasuk variabel terikat) dan $\mathrm{N}=80$ besar nilai dl $($ batas bawah $)=1,5600$ dan du $($ batas atas $)=1,7153 ; 4-\mathrm{dl}=2,400$ dan $4-\mathrm{du}=2,2847$. Dengan melihat kriteria pada pedoman Durbin-Watson maka nilai du $<\mathrm{d}<4$-du atau 1,7153 $<1,906<2,2847$ maka dari hasil uji Autokorelasi dapat diambil kesimpulan tidak terjadi autokorelasi positif dan negatif.

Uji Heteroskedastisitas. Model regresi yang baik adalah tidak terjadi heteroskedastisitas. Pada penelitian ini cara mendeteksi ada tidaknya gejala heteroskedastisitas adalah menggunakan grafik scatterplot dan uji glejser yang dilakukan dengan menguji kekuratan hasil uji heteroskedastisitas. Berikut uji heteroskedastisitas dapat dilihat dari grafik scatterplot.

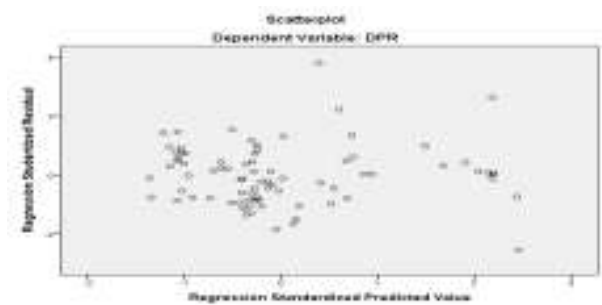

Gambar 4. Uji Scatterplot

Sumber : Hasil Pengolahan Data,2018

Dari grafik scatterplot terlihat bahwa titik-titik menyebar secara acak baik diatas maupun dibawah angka nol (0) pada sumbu Y, tidak berkumpul disatu tempat, sehingga dari grafik scatterplot dapat disimpulkan bahwa tidak terjadi heteroskedastisitas pada model regresi. Pendeteksian ada tidaknya heteroskedastisitas bisa juga dilakukan dengan menggunakan uji glejser, berikut hasil uji nya :

Tabel 6. Uji Glejser

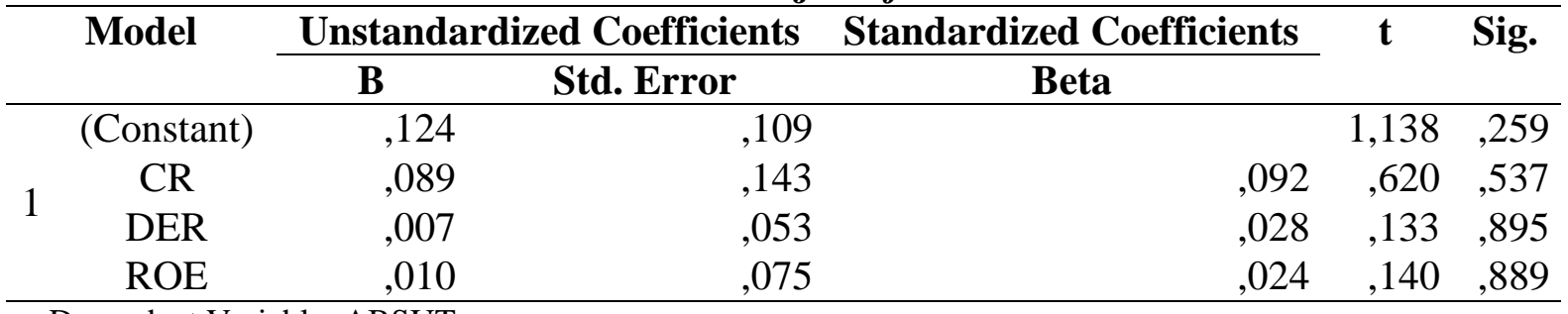

a. Dependent Variable: ABSUT

Sumber : Hasil Pengolahan Data, 2018

Hasil Uji glejser Pada Tabel 7 di atas menunjukkan nilai signifikan dari 3 variabel independen yaitu Current Ratio 0,537 > 0,05 Debt to Equity Ratio 0,895 > 0,05 dan Return on Equity 0,889 > 0,05 dengan demikian dari hasil uji Glejser dapat disimpulkan tidak terjadi masalah Heteroskedastisitas.

Model Penelitian. Pengujian hipotesis yang digunakan dalam penelitian adalah dengan menggunakan analisis regresi linier berganda. Model regresi yang digunakan adalah sebagai berikut :

$$
\begin{gathered}
\text { Dividend Payout Ratio }=0,184+0,337 \text { Current Ratio }-0,089 \text { Debt to Equity Ratio+ 0,629 } \\
\text { Return on Equity }
\end{gathered}
$$

Makna dari persamaan regresi linier berganda di atas adalah :

1. Konstanta sebesar 0,184satuan menyatakan bahwa jikaCurrent Ratio, Debt to Equity Ratio, dan Return on Equity konstan (tetap) maka Dividend Payout Ratio sebesar 0,184 satuan. 
2. Koefisien regresi Current Ratiosebesar 0,337 satuan menyatakan bahwa setiap kenaikan 1 satuan Current Ratioakan menyebabkan peningkatan Dividend Payout Ratio sebesar 0,337 satuan.

3. Koefisien regresi Debt to Equity Ratio sebesar -0,089 satuan menyatakan bahwa setiap kenaikan1 satuanDebt to Equity Ratioakan menyebabkan penurunan Dividend Payout Ratio sebesar 0,089 satuan.

4. Koefisien regresi Return on Equity sebesar 0,629 satuan menyatakan bahwa setiap kenaikan1 satuanReturn on Equity akan menyebabkan peningkatan Dividend Payout Ratio sebesar 0,629 satuan.

Koefisien Determinasi Hipotesis. Koefisien determinasi ditujukan untuk mengetahui seberapa besar kemampuan model dalam menerangkan variabel terikat. Jika koefisien determinasi $\left(\mathrm{R}^{2}\right)$ semakin besar atau mendekati 1, maka dapat dikatakan bahwa kemampuan variabel bebas $(\mathrm{X})$ adalah besar terhadap variabel terikat $(\mathrm{Y})$.

Tabel 7. Uji Koefisien Determinasi

\begin{tabular}{ccccr}
\hline Model & R & R Square & Adjusted R Square & Std. Error of the Estimate \\
\hline 1 &, $614^{\mathrm{a}}$ &, 377 &, 352 &, 251321 \\
\hline $\begin{array}{l}\text { a. Predictors: (Constant), ROE, CR, DER } \\
\text { Sumber : Hasil Pengolahan Data, } 2018\end{array}$ & & \\
\end{tabular}

Berdasarkan Tabel 7 hasil Uji Koefisien Determinasi diperoleh nilai Adjusted $R$ Square sebesar 0,352 hal ini berarti mengindikasi bahwa variasi dari Current Ratio, Debt to Equity Ratio dan Return on Equity menjelaskan Dividend Payout Ratio sebesar35,2\% sedangkan sisanya sebesar $64,8 \%$ dipengaruhi oleh variabel lain yang tidak diteliti sepertiReturn on Asset, Asset Growth, Cash Ratio dan lainnya.

Pengujian Hipotesis Secara Simultan. Uji F digunakan untuk menunjukkan apakah semua variabel independen yang dimasukkan dalam model mempunyai pengaruh secara bersama-sama terhadap variabel dependen.

Tabel 8. Uji F

\begin{tabular}{rrrrrrr}
\hline & Model & Sum of Squares & df & Mean Square & F & Sig. \\
\hline \multirow{4}{*}{1} & Regression & 2,900 & 3 &, 967 & 15,303 &, $000^{\mathrm{b}}$ \\
& Residual & 4,800 & 76 &, 063 & & \\
& Total & 7,700 & 79 & & & \\
\hline
\end{tabular}

a. Dependent Variable: DPR

b. Predictors: (Constant), ROE, CR, DER

Sumber : Hasil Pengolahan Data, 2018

Uji signifikansi simultan/bersama-sama menghasilkan nilai $\mathrm{F}$ hitung sebesar 15,303. Pada derajat bebas $1\left(\mathrm{df}_{1}\right)=\mathrm{k}=3$, dan derajat bebas $2\left(\mathrm{df}_{2}\right)=\mathrm{n}-\mathrm{k}-1=80-3-1=76$, dimana $\mathrm{n}=$ jumlah sampel, $\mathrm{k}=$ jumlah variabel independen, maka nilai $\mathrm{f}$ tabel pada taraf kepercayaan signifikansi 0,05 adalah 2,72. $\mathrm{F}$ hitung $=15,303>\mathrm{F}$ tabel $=2,72$ dengan tingkat signifikansi 0,000. Karena $\mathrm{F}$ hitung $>\mathrm{F}$ tabel dan signifikansi $<0,05$ maka $\mathrm{H}_{\mathrm{a}}$ diterima artinya secara bersama-sama Current Ratio, Debt to Equity Ratio danReturn on Equity berpengaruh terhadap Dividend Payout Ratio pada perusahaanIndustri barang konsumsi yang terdaftar di BEI periode 2013-2017.

Pengujian Hipotesis Secara Parsial. Pengujian t-test digunakan untuk menunjukkan seberapa jauh pengaruh satu variabel independen terhadap variabel dependen. 
Tabel 9. Uji t

\begin{tabular}{|c|c|c|c|c|c|c|}
\hline & \multirow[t]{2}{*}{ Model } & \multicolumn{2}{|c|}{ Unstandardized Coefficients } & Standardized Coefficients & \multirow[t]{2}{*}{$\mathbf{t}$} & \multirow[t]{2}{*}{ Sig. } \\
\hline & & B & Std. Error & Beta & & \\
\hline \multirow{4}{*}{1} & (Constant) &, 184 &, 170 & & 1,081 & 283 \\
\hline & $\mathrm{CR}$ & ,337 & 222 &, 17 & 1,514 & 134 \\
\hline & DER &,- 089 & 082 &,- 17 & $-1,083$ & 282 \\
\hline & ROE & 629 & 116 &, 74 & 5,398 &, 000 \\
\hline
\end{tabular}

a. Dependent Variable: DPR

Sumber : Hasil Pengolahan Data,2018

Nilai t tabel untuk probabilitas 0,05 pada derajat bebas 76 adalah sebesar 1,99167. Dengan demikian hasil dari Uji t dapat dijelaskan sebagai berikut:

1. Nilai $\mathrm{t}$ hitung $>\mathrm{t}$ tabel atau $1,514<1,99167$ dan signifikan $0,134>0,05$ maka $\mathrm{H}_{0}$ diterima artinya secara parsial Current Ratio tidak berpengaruhterhadap Dividend Payout Ratio pada perusahaanIndustri barang konsumsi yang terdaftar di BEI periode 2013-2017.

2. Nilai -t hitung > -t tabel atau -1,083> -1,99167 dan signifikan 0,282 > 0,05 maka $\mathrm{H}_{0}$ diterima artinya secara parsialDebt to Equity Ratiotidak berpengaruh terhadapDividend Payout Ratio pada perusahaanIndustri barang konsumsi yang terdaftar di BEI periode 2013-2017.

3. Nilai t hitung $>t$ tabel atau 5,398>1,99167 dan signifikan 0,000 $<0,05$ maka $\mathrm{H}_{\mathrm{a}}$ diterima artinya secara parsial Return on Equity berpengaruh positif dan signifikan terhadap Dividend Payout Ratio pada perusahaan Industri barang konsumsi yang terdaftar di BEI periode 2013-2017.

\subsection{Pembahasan}

Pengaruh Current Ratio Terhadap Dividend Payout Ratio. Berdasarkan hasil pengujian secara parsial bahwa Current Ratio tidak berpengaruh terhadap Dividend Payout Ratio pada perusahaan industri barang konsumsi periode 2013-2017. Hasil penelitian ini tidak sejalan dengan hipotesis. Hasil penelitian ini tidak sejalan dengan hasil penelitian Rahayu dan Hari(2016)dengan judul Pengaruh CurrentRatio dan Quick Ratio terhadap Kebijakan Dividen Melalui Return On Equity Pada Perusahaan Manufaktur yang Terdaftar di BEI Tahun 2014 dimana hasil penelitian ini juga menunjukkan Current Ratiotidak berpengaruh signifikan terhadap Dividend Payout Ratio. Hasil penelitian ini tidak sejalan dengan teori Sudana (2011:170), Dividen dapat dibayarkan dalam bentuk dividen tunai atau dividen saham. Perusahaan hanya mampu membayar dividen tunai jika tingkat likuiditas (current ratio) yang dimiliki perusahaan mencukupi. Semakin tinggi tingkat likuiditas perusahaan, semakin besar dividen tunai yang mampu dibayar perusahaan kepada pemegang saham dan sebaliknya. Berdasarkan hasil penelitian perubahan Current Ratio tidak akan mempengaruhi tingkat kebijakan dividen perusahaan, hal ini kemungkinan perusahaan memiliki aktiva lancar yang kurang produktif. Contohnya kas yang tidak digunakan secara efisien, piutang yang kurang produktif (sudah jatuh tempo) serta persediaan yang menumpuk (sehingga dapat menyebabkan kerusakan dan kadaluarsa) yang dapat menyebabkan kerugian sehingga perusahaan tidak dapat membagikan dividen.

Pengaruh Debt to Equity Ratio Terhadap Dividend Payout Ratio. Berdasarkan hasil pengujian secara parsial bahwa Debt to Equity Ratio tidak berpengaruh terhadap Dividend Payout Ratio pada perusahaan industri barang konsumsi tahun 2013-2017. Hasil penelitian ini tidak sejalan dengan hipotesis. Hasil penelitian ini sejalan dengan penelitian yang dilakukan oleh Astiti, dkk (2017) dengan judul Pengaruh Debt to Equity Ratio (DER), CurrentRatio (CR), Net Present Margin (NPM), Return on Asset (ROA), Terhadap Dividend Payout Ratio (DPR) Studi Pada Perusahaan Basic Industry dan Properti, Real Estate \& 
Building Contruction Yang Terdaftar Di Bursa Efek Indonesia Periode 2011-2015 dimana hasil penelitian menunjukkan Debt to Equity Ratio tidak berpengaruh signifikan terhadap Dividend Payout Ratio. Hasil penelitian ini tidak sejalan dengan teori Hery (2013:37), jika beban utang semakin tinggi maka kemampuan perusahaan untuk membagi dividen akan semakin rendah. Berdasarkan hasil penelitian Debt to Equity Ratio tidak berpengaruh terhadap dividen payout ratio, hal ini menunjukkan perusahaan yang memiliki tingkat hutang yang tinggi belum tentu memiliki pembagian dividen yang kecil. Dimana penggunaan hutang tersebut memberikan manfaat bagi perusahaan sehingga perusahaan dapat melakukan perluasan usaha dan meningkatkan profit sehingga dividen yang dibayarkan pun meningkat.

Pengaruh Return on Equity Terhadap Dividend Payout Ratio. Berdasarkan hasil pengujian secara parsial bahwa Return on Equity signifikan berpengaruh positif terhadap Dividend Payout Ratio pada perusahaan industri barang konsumsi tahun 2013-2017. Hasil ini sejalan dengan hipotesis. Hasil penelitian ini sejalan dengan penelitian yang dilakukan oleh Kartika, dkk (2015), bahwa Return on Equity berpengaruh positif dan signifikan terhadap Dividend Payout Ratio. Hasil penelitian ini sejalan dengan teori Rodoni dan Ali (2014:117) perusahaan besar yang sudah mempunyai profitabilitas yang tinggi dan keuntungan yang stabil akan lebih mudah memasuki pasar modal atau memperoleh dana dari luar untuk pembiayaannya. Karena itu perusahaan yang sudah mantap akan mempunyai tingkat dividen yang lebih tinggi dibanding dengan perusahaan kecil atau masih baru. Berdasarkan hasil penelitian Return on Equity berpengaruh positif dan signifikan terhadap Dividend Payout Ratio artinya semakin tinggi profit maka akan semakin tinggi juga rasio pembagian dividen perusahaan. Hal ini dikarenakan pembagian dividen berasal dari sebagian laba yang diperoleh perusahaan. Dengan demikian sector industry barang industry memiliki kinerja profit yang baik karena didukung oleh jumlah penduduk yang tinggi dan tingkat konsumsi yang tinggi yang berdampak pada peningkatan keuntungan perusahaan. Semakin tinggi keuntungan yang didapatkan oleh perusahaan maka akan semakin tinggi juga keuntungan yang dapat dinikmati oleh pemegang saham dalam bentuk pembagian dividen.

\section{KESIMPULAN DAN SARAN}

\subsection{Kesimpulan}

Kesimpulan dari hasil penelitian ini adalah:

1. Current Ratio tidak berpengaruh signifikan terhadap Dividend Payout Ratio pada perusahaanIndustri barang konsumsi yang terdaftar di BEI periode 2013-2017 dengan nilai t hitung $(1,514)>t$ tabel $(1,99167)$ dan signifikan $0,134>0,05$.

2. Debt to Equity Ratio tidak berpengaruhsignifikan berpengaruhterhadap Dividend Payout Ratio pada perusahaanIndustri barang konsumsi yang terdaftar di BEI periode 2013-2017 dengan nilai -t hitung $(-1,083)>-t$ tabel $(-1,99167)$ dan signifikan $0,282>0,05$.

3. Return on Equityberpengaruh positif dan signifikan terhadap Dividend Payout Ratio pada perusahaanIndustri barang konsumsi yang terdaftar di BEI periode 2013-2017 dengan nilai t hitung $(5,398)>t$ tabel $(1,99167)$ dan signifikan $0,000<0,05$.

4. Current Ratio, Debt to Equity Ratio, danReturn on Equity berpengaruh terhadap Dividend Payout Ratio pada perusahaanIndustri barang konsumsi yang terdaftar di BEI periode 2013-2017 dengan nilai $\mathrm{F}$ hitung $=15,303>\mathrm{F}$ tabel $=2,72$ dan tingkat signifikan sebesar $0,000<0,05$ serta hasil Koefisien Determinasi sebesar 0,352 hal ini berarti mengindikasi bahwa variasi dari Current Ratio, Debt to Equity Ratio, danReturn on Equity menjelaskan Dividend Payout Ratio sebesar35,2\% sedangkan sisanya 64,8\%dipengaruhi oleh variabel lain yang tidak diteliti. 


\subsection{Saran}

Saran dari hasil penelitian ini adalah:

1. Bagi perusahaan, penentuan besarnya Dividend Payout Ratio merupakan masalah penting bagi setiap perusahaan karena dapat mempengaruhi nilai perusahaan di mata investor. Oleh karena itu sebaiknya manajemen perlu mempertimbangkan variabelvariabel yang mempengaruhi Dividend Payout Ratio, dalam hal ini Return on Equity.

2. Bagi Universitas Prima Indonesia, disarankan agar dapat mempublikasikan hasil penelitian ini untuk kepentingan penelitian selanjutnya.

3. Bagi peneliti selanjutnya, disarankan untuk menambah variabel lain di luar dari variabel yang diteliti oleh peneliti. Karena hasil uji koefisien menunjukkan 64,8\% dari variasi variabel Dividend Payout Ratio dipengaruhi oleh variabel lain misalnya likuiditas, good corporate governance dan lainnya.

4. Bagi investor, disarankan untuk melihat indikator Return on Equityapabila ingin mengetahui faktor-faktor yang mempengaruhi Dividend Payout Ratio .

\section{DAFTAR PUSTAKA}

Ghozali, Imam. 2013. Aplikasi Analysis Multivariate dengan Program SPSS.Cetakan IV, Semarang: Penerbit BP-Universitas Diponegoro.

Harahap. 2013. Analisis Kritis atas Laporan Keuangan. Jakarta : PT Raja Grafindo Persada.

Hery. 2015. Analisis Laporan Keuangan. Jakarta: Bumi Aksara.

Horne, James C. Van dan John M. Wachowicz. 2014. Prinsip-Prinsip Manajemen Keuangan. Jakarta : Penerbit Salemba Empat.

Jusuf, Jopie. 2008. Analisis Kredit untuk Account Officer. Jakarta: PT. Gramedia Pustaka Utama.

Keown, dkk. 2008. Manajemen Keuangan. Ed.10, PT. Macana Jaya Cemerlang.

Murhadi, Werner R. 2015. Analisis Laporan Keuangan : Proyeksi dan Valuasi Saham. Jakarta: Penerbit Salemba Empat.

Samryn. 2013. Akuntansi Manajemen Informasi Biaya untuk Mengendalikan Aktivitas Operasi \& Investasi. : Jakarta: Prenada Media Grup (Kencana).

Sudana, I Made. 2011.Manajemen Keuangan Perusahaan: Teori \& Praktik. Jakarta: Penerbit Erlangga.

Syahyunan. 2013. Manajemen Keuangan 1 (Perencanaan, Analisis dan Pengendalian keuangan. Medan: USU Press.

Wahyudiono, Bambang. 2014. Mudah Membaca Laporan Keuangan. Jakarta : Raih Asa Sukses.

Zulganef. 2008. Metode Penelitian Sosial Dan Bisnis. Yogyakarta: Graha Ilmu. 